\title{
Performance comparison and impact of weather conditions on different photovoltaic modules in two different cities
}

\author{
Caouthar Bahanni' ${ }^{1}$, Mustapha Adar ${ }^{1}$, Sofia Boulmrharj ${ }^{2}$, Mohammed Khaidar ${ }^{2}$, Mustapha Mabrouki $^{1}$ \\ ${ }^{1}$ Industrial Engineering Laboratory, Faculty of Sciences and Technologies, Sultan Moulay Slimane University, Beni Mellal, Morocco \\ ${ }^{2}$ CUR ’EnR\&SIE”, Faculty of Sciences El Jadida, Chouaib Doukkali University, El Jadida, Morocco
}

\begin{tabular}{|c|c|}
\hline Article Info & ABSTRACT \\
\hline $\begin{array}{l}\text { Article history: } \\
\text { Received Jul 2, } 2021 \\
\text { Revised Jan 4, } 2022 \\
\text { Accepted Jan 19, } 2022\end{array}$ & $\begin{array}{l}\text { This work is based on a comparative study of the impact of meteorological } \\
\text { conditions as well as the assessment of the production performance of two } \\
\text { identical photovoltaic stations installed in two Moroccan cities, the stations } \\
\text { are based on three different technologies. The measures of one year of } \\
\text { operation from January } 2017 \text { to December } 2017 \text { were evaluated. The annual } \\
\text { average performance ratios were found to be } 82.42 \%, 79.99 \% \text { and } 78.74 \% \text { in }\end{array}$ \\
\hline $\begin{array}{l}\text { Keywords: } \\
\text { Performance analysis } \\
\text { photovoltaic silicon } \\
\text { technologies } \\
\text { PV efficiency } \\
\text { PV system } \\
\text { Weather conditions impact }\end{array}$ & $\begin{array}{l}\text { Beni Mellal, and } 85.29 \%, 84.61 \% \text { and } 70.41 \% \text { in El Jadida for the } \\
\text { polycrystalline (pc-Si), monocrystalline (mc-Si), and amorphous (a-Si) } \\
\text { respectively. The photovoltaic efficiency was calculated at } 12.24 \%, 11.89 \% \text {, } \\
\text { and } 11.71 \% \text { in Beni Mellal; and } 12.59 \%, 12.49 \% \text {, and } 10.42 \% \text { in El Jadida } \\
\text { by the same order. Statistical analysis was carried out to establish the } \\
\text { correlation with photovoltaic (PV) production showed that after irradiation, } \\
\text { the temperature is the most influencing meteorological factor for PV } \\
\text { production, revealing a degradation in the performance ratio of } 2.5 \%, 2 \% \text {, } \\
\text { and } 1 \% \text { for each increase of } 8{ }^{\circ} \mathrm{C} \text { in temperature for monocrystalline, } \\
\text { polycrystalline and amorphous technologies respectively at Beni Mellal. } \\
\text { While at El Jadida the reduction in the performance ratio is evaluated by } \\
5.5 \%, 5.2 \% \text {, and } 3 \% \text { for each } 8{ }^{\circ} \mathrm{C} \text { increase in temperature for the same } \\
\text { order. }\end{array}$ \\
\hline
\end{tabular}

This is an open access article under the $\underline{C C B Y-S A}$ license.

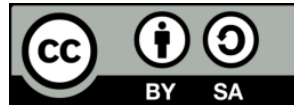

\section{Corresponding Author:}

Bahanni Caouthar

Industrial Engineering Laboratory, Faculty of Sciences and Technologies

Sultan Moulay Slimane University

Mghila Campus, BP 523, 23000, Beni Mellal, Morocco

Email: Caouthar.bahanni@usms.ma

\section{INTRODUCTION}

Solar energy in Morocco is a critical economic subject consistent with sustainable development. The risks are consequently doubly high, agreed with the unrestrained growth in the costs of traditional energies, which are having a negative influence on the environment. With 3,000 hours of sunshine per year and an average irradiation of more than $5 \mathrm{kWh} / \mathrm{m}^{2}$, Morocco has considerable solar potential. The country intends to massively take advantage of this clean and inexhaustible energy. It is increasingly asserting itself as an investment destination in the clean energy sector.

In this logic the project "Propre.ma" thrown, is an ambitious program at a national scale financed by research institute for solar energy and new energies (IRESEN), linking all the Moroccan public universities in 20 cities for the development of a mapping of the photovoltaic producible in Morocco. Currently, research in the arena of photovoltaic solar energy is increasingly dynamic. Besides, most studies focus on refining the conversion of solar radiation into electrical energy [1]. In general, there are several technologies of photovoltaic cells, the most dominant by $97 \%$ in the world in 2018 [2], and which represents the best 
performance is that based on crystalline silicon, barely the amorphous silicon which is part of the thin films becomes more and more competitive with crystalline silicon under certain weather conditions (more details on photovoltaic technologies in [3]).

The environmental conditions under which the photovoltaic modules are called upon to operate in real conditions (temperature, humidity, wind, irradiation, and dust) must be taken into account given their crucial impact on photovoltaic production [1], [4], [5]. Particularly in Morocco, which is characterized by a climate conditions placing the photovoltaic systems during their most operating time outside the standard test conditions (STC): corresponding to a temperature of $25^{\circ} \mathrm{C}$ and sunshine of $1000 \mathrm{~W} / \mathrm{m}^{2}$; consequently, this makes the evolution of the performance of modules increasingly problematic. For this purpose, several works have taken this sense of study to always remind us to pose this issue [6]-[8].

Nour-eddine et al. [9] worked on the same kind of our present work on a PV installation similar to those used here, all within the framework of the "Propre.ma" project; The results showed that the performance ratio of $\mathrm{p}$-Si (polycrystalline) technology is higher compared to that of $\mathrm{m}$-Si (monocrystalline) technology during the hottest months of the year, which explains the impact of temperature on the PV production. Roumpakias and Stamatelos [10] studied the deterioration of PV efficiency and deviations from STC conditions, using data from a grid-connected photovoltaic park of $99.84 \mathrm{kWp}$ in central Greece. This study was performed for a three-year period (from 2013 to 2015). The results extracted from these studies showed that the efficiency of PV modules during the two primary years was found to be higher than the STC conditions, while during the third year, a slight decrease in efficiency compared to the STC conditions has been registered. However, the behavior of PV efficiency decreases over time. Jed et al. [11] presented a performance assessment of a $954,809 \mathrm{kWp}$ photovoltaic plant of micro-amorphous silicon situated in Nouakchott, using one-year data of operation from September 2014 to August 2015, the authors find as results that the photovoltaic array performances rest on both illumination and climatic conditions, whilst wind speed variation does not influence those energies.

Al-Addous et al. [12] presented a performance evaluation work of an off-grid PV system in Jordan valley in which a four-year historical meteorological database was used for the development of a model to estimate the effect of temperature on electricity production. Indeed, with prior knowledge of the site which is characterized by a high temperature, the results denote that the PV efficiency is strongly affected by the increase in temperature, and thanks to a cooling system, the authors observed a nearly $2 \%$ improvement in efficiency in different radiation modalities. Elibol et al. [13] applied performance tests on a PV plant installed on the roof of the scientific and technological research and application center of Düzce University (DUBIT) in Düzce province, Turkey. Among these tests, the authors carried out an examination of the variations of the panels energy conversion efficiency according to the temperature; the results of this examination showed that when increasing the temperature by $1{ }^{\circ} \mathrm{C}$ the efficiency of pc-Si and a-Si technology increases by $0.033 \%$ and $0.029 \%$ respectively, while the efficiency of mc-Si technology decreases by $0.084 \%$. Daher et al. [14] presented a research work in which the impact of tropical desert maritime climate on the performance of a PV grid-connected power plant was analyzed, the results show that the average PR for PV arrays and the global grid-connected system was found to be $90 \%$ and $84 \%$ respectively, while the monthly average daily PV module efficiencies of $12.68 \%$. from these results, the authors deduce that the ambient temperature has an impact on the performance ratio, estimated by a decrease of $0.7 \%$ for each increase of $1{ }^{\circ} \mathrm{C}$ in the daily ambient temperature. In the literature many works are used performance indicators such as performance ratio, capacity factor, final yield to analyze the performance of PV plants [15]-[17]. Other analyzed the impact of meteorological conditions in their PV plant [18]-[20].

This paper aims to compare the evaluation of energy performance and to analyze. The impact of environmental conditions on monocrystalline, polycrystalline, and amorphous photovoltaic modules under the climate of Beni Mellal and El Jadida cities (in Morocco). This performance analysis is made up based on the international energy agency norms (IEA) [21].

\section{PV PLANT DESCRIPTION}

The photovoltaic plants of Beni Mellal and El Jadida were installed on the rooftop of the Faculty of Sciences and Techniques shown in Figure 1 and the Faculty of Science shown in Figure 2 respectively. Each station generates in totality $6 \mathrm{KWp}$ where $2 \mathrm{kWp}$ produced by each silicon technology (monocrystalline (mc$\mathrm{Si}$ ), polycrystalline (pc-Si) and amorphous (a-Si)). All descriptions of the plants will be found in [1], [22]-[24]. In addition to the photovoltaic system, the plants also consist of similar weather stations in each city described briefly in [25]. 


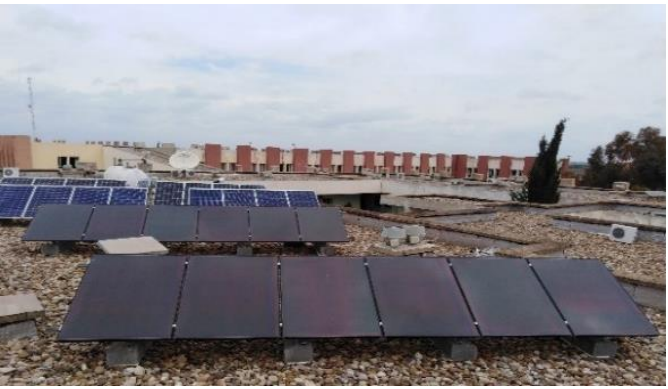

Figure 1. Beni Mellal PV plant

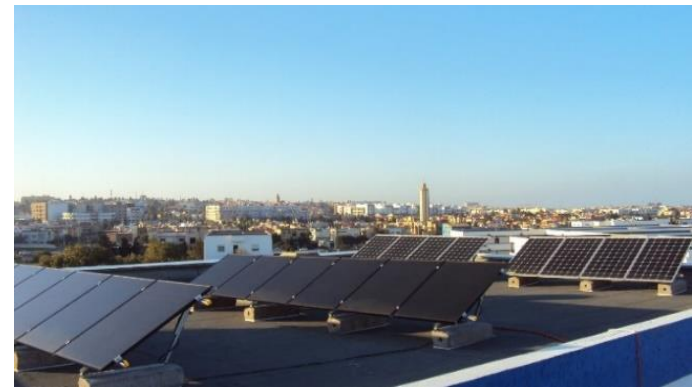

Figure 2. El Jadida PV plant

\subsection{Site of PV plants}

Table 1 summarizes the geographical coordinates and the value of certain meteorological parameters of the two different cities where the photovoltaic installations are located. Beni Mellal city has a very hot dry climate in summer and very cool in winter, while El Jadida is characterized by a Mediterranean climate that is also hot in summer and cool in winter. According to the Koppen-Geiger classification [26], the climates of both cities (Beni Mellal and El Jadida) are classified as Csa type. However, by comparing the average temperatures of the two cities we see that Beni Mellal has a very hot climate in summer and also very cool in winter compared to El Jadida which will influence the production yield in both locations. Figure 3 shows the Moroccan map with the geographic locations of PV plants in the cities of Beni Mellal and El Jadida [27], [28].

Table 1. Geographic coordinates, mean temperature and global horizontal irradiation of cities

\begin{tabular}{lcc}
\hline \multicolumn{1}{c}{ Beni Mellal } & El Jadida & Beni Mellal \\
\hline Latitude & $32^{\circ} 20^{\prime}$ North & $33^{\circ} 14^{\prime}$ North \\
Longitude & $6^{\circ} 21^{\prime}$ West & $8^{\circ} 30^{\prime}$ West \\
Average temperature & 23,47 & 21,67 \\
Overall horizontal Irradiation $\left(\mathrm{kWh} / \mathrm{m}^{2} /\right.$ year $)$ & 2392,87 & 2268,81 \\
\hline
\end{tabular}

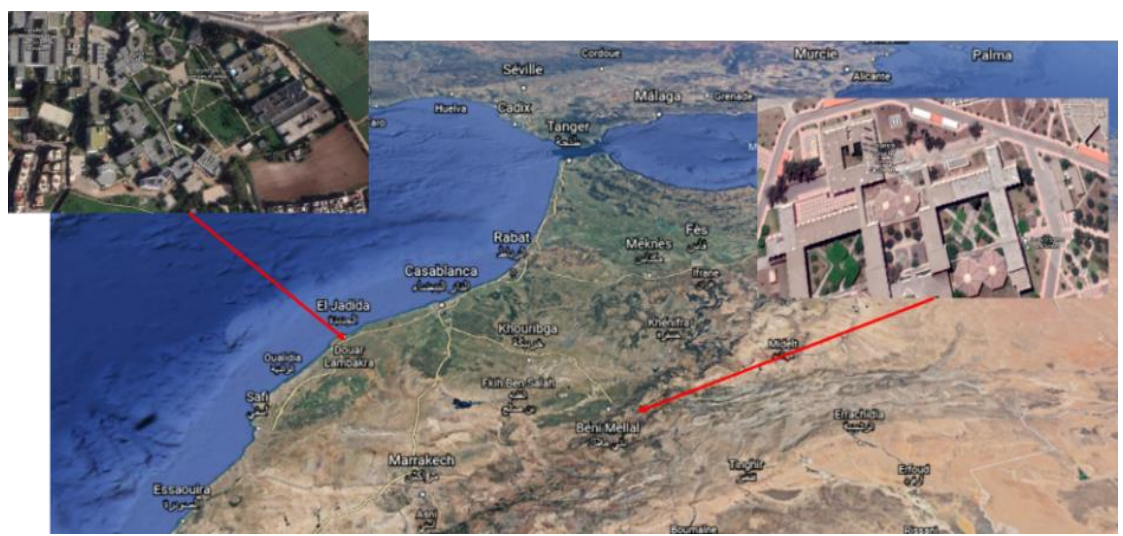

Figure 3. Moroccan map with geographic locations of the PV plants

\section{PERFORMANCE INDICATORS}

\subsection{Energy production}

Monthly energy production is the amount of energy that a PV system can produce in each month of the year. It is considered as the main parameter in the performance evaluation of PV systems. This parameter is also used to assess the degradation of PV modules.

\subsection{The reference yield ( $Y r)$}

The reference yield $\mathrm{Yr}$ is the total solar radiation in the plane $\mathrm{Ht}(\mathrm{kWh} / \mathrm{m} 2)$ divided by the PV's reference irradiance G0 $(\mathrm{kW} / \mathrm{m} 2)$. It represents the number of hours of which the illumination is equivalent to the reference irradiance. The Yr defines the solar resource for the PV system. It depends on several criteria such as the orientation of the photovoltaic modules, the location, and variability of weather conditions depending on the time. 


$$
\mathrm{Y}_{\mathrm{r}}=\frac{\mathrm{Ht}}{\mathrm{GO}}
$$

\subsection{The final yield (Yf)}

The final yield of the PV system Yf, is the net energy Eg $(\mathrm{kWh})$ produced by the PV system, divided by the nominal power P0 (kWp) of the installed photovoltaic module. This quantity represents the number of hours during which the photovoltaic system operate at its nominal power. Reads as (2).

$$
\mathrm{Y}_{\mathrm{f}}=\frac{\mathrm{EDC}}{\mathrm{P} 0}
$$

\subsection{Performance ratio}

The performance ratio (PR), is an essential parameter to assess the quality of the PV installation; it makes it possible to quantify the performance of the photovoltaic installations. It shows the relationship between theoretical energy and real energy generated by a PV system. The performance ratio is a number between 0 and $100 \%$ (or 0 and 1). The closer it is to $100 \%$ (or to 1), the more efficient the installation is, from an electrical point of view. Considering that every photovoltaic installation is unique while losses cannot be avoided, an installation with a performance ratio of up to $80 \%$ is considered to be a highperformance PV installation. The PR is expressed as (3).

$$
\mathrm{PR}=\frac{\mathrm{Yf}}{\mathrm{Yr}}
$$

\subsection{Array yield (Ya)}

The array yield, defined as the ratio between the total energy produced by the photovoltaic generator (EDC) during a distinct period (day, month or year), and the nominal power of the PV system P0. It represents the number of hours during which the PV panel needs to operate at its nominal power. The (Ya) is expressed as (4).

$$
\mathrm{Ya}=\frac{\mathrm{EDC}}{\mathrm{PO}}
$$

\subsection{Energy density}

The energy density (ED), is an indicator used in the choice of solar photovoltaic technologies. ED represents the energy produced by a solar photovoltaic system in a period of time (month and year) per unit area of modules [21]. It is measured to be aware of the optimization of the space available for electricity production by the PV plant.

$$
\mathrm{ED}=\frac{\mathrm{EDC}}{\mathrm{Am}}
$$

Am: is the total area of the module plane.

\subsection{Capacity factor}

The capacity factor $\mathrm{CF}$, is an indicator measured to represent the energy generated by a PV system. It is defined as the ratio of actual monthly energy output to the quantity of energy the PV system can deliver at its rated capacity for $24 \mathrm{~h}$ per day during the month. The CF is expressed as (6).

$$
\mathrm{CF}=\frac{\mathrm{Yf}(\text { monthly) }}{24 \mathrm{~h} * \mathrm{~N}}
$$

$\mathrm{N}$ : Number of days during each month.

\subsection{PV efficiency}

PV efficiency remains the efficient energy produced by a PV module in terms of available radiation, it tells us how effective a solar panel is in transforming irradiance into useful electricity through the photovoltaic effect. PV efficiency described as the ratio of the energy production to the product of the surface area and the irradiation received on the surface of the PV modules. The PV is expressed as (7).

$$
\mathrm{h}_{\mathrm{pv}}=\frac{\mathrm{EDC}}{\mathrm{Am} * \mathrm{Ht}}
$$




\section{RESULT AND DISCUSSION}

\subsection{Correlation analysis}

To find out the meteorological parameter most influencing the photovoltaic production in the two cities, we studied the correlation between the meteorological parameters (irradiation, temperature, wind speed and humidity) and the energy produced (EAC). Figures 4 and 5 show the results of this correlation represented in the form of two correlation matrixes found by analyzing -using python programming- the meteorological and production data of the two installations (Beni Mellal and El Jadida, respectively) on which we observe that: Irradiation is still the parameter most correlated with production for the three technologies of the two installations in the two cities, which is logical since the panels can only operate with a solar radiance. The second parameter that influences production is the temperature also for the three technologies in the two cities. The temperature influences the performance of the panels in a more or less uneven way for each installation (Beni Mellal and El Jadida). Wind speed is the third parameter influencing photovoltaic production followed by humidity, which is considered as the last parameter influencing photovoltaic production.

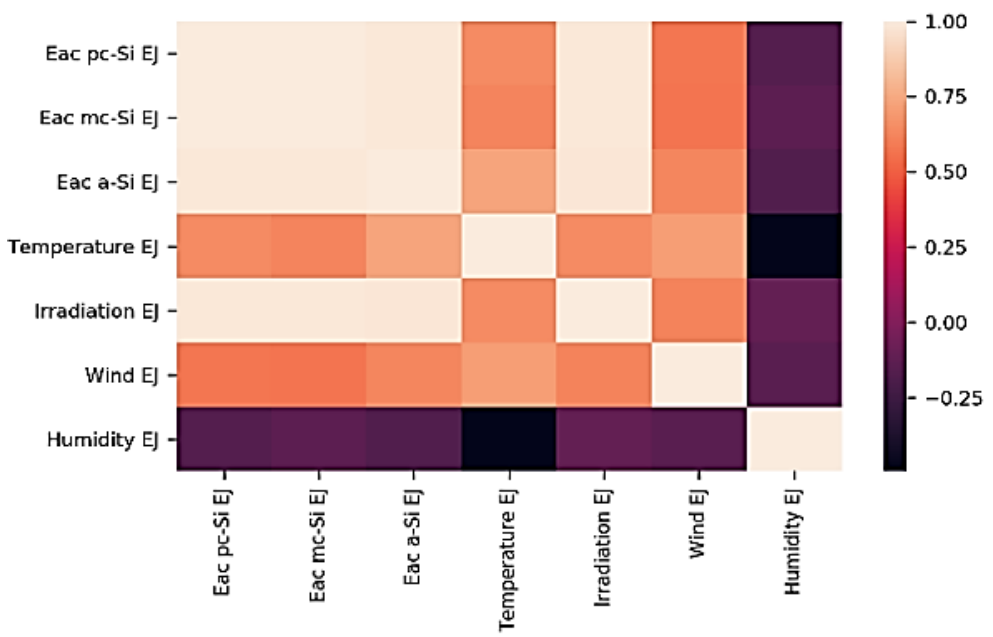

Figure 4. Correlation matrix of Beni Mellal PV plant

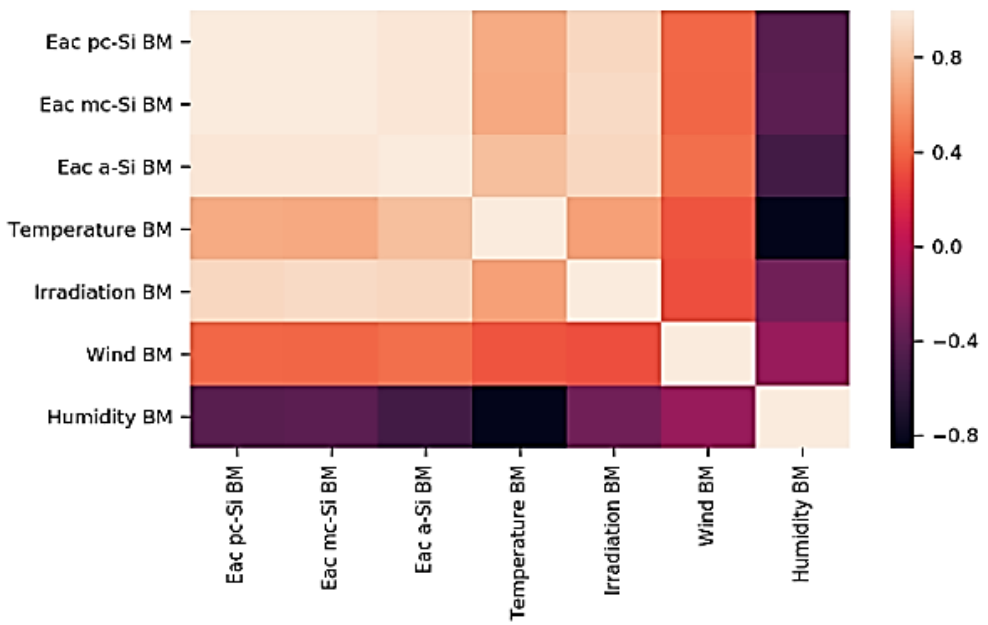

Figure 5. Correlation matrix of El Jadida PV plan

From these results, it was agreed for the three technologies of the two installations that the order of the correlation with the EAC production is as follows: i) irradiation, ii) temperature, iii) wind speed, and iv) humidity. From the results of the final yield YF, it can be observed that polycrystalline technology is the most beneficial in Beni Mellal, followed by monocrystalline technology while amorphous represents the 
leastefficient technology among those three. These results briefly explain the order of the correlation between the energy produced EAC of the three technologies and irradiation. Indeed, irradiation represents the first factor influencing the production of electricity by PV panels [29], although it is obvious that it is the first parameter correlated with PV production, that is to say, it is obviously logical that there will be a decrease in PV production with the decrease in irradiation and vice versa. Indeed, temperature is the second parameter that influences PV production for the three technologies. From the results we see that the ambient temperature induces a noticeable effect on the photovoltaic production, this is explained by the great influence of the ambient temperature on the panels temperature and therefore of the photovoltaic cells. In fact, it appears that more the temperature of the cell increases, more the power of the latter decreases, because the temperature of a photovoltaic cell affects its voltage and the power of the cell being equal to the product of the current and the voltage. On top of that, the wind speed is considered as the third parameter that influences photovoltaic production. Although the wind speed does not have a big influence on the production, but it has a more or less important role in the cooling of solar panels and therefore the improvement of the production. Lastly, we can observe that the increase in the air humidity rate generates frequent cloud cover formation and lasting, thus, making the control of the electricity production by solar panels delicate and more difficult, nevertheless this influence is not crucial, which make humidity turns out to be the last parameter that influences photovoltaic production.

\subsection{Impact of weather conditions}

\subsubsection{Irradiation}

Figures 6 and 7 represent the impact of irradiation on the photovoltaic production of the three technologies in the two cities (Beni Mellal and El Jadida) respectively. The results show that the irradiation always follows the same behavior of the PV production for the three technologies, this shows the great irradiation impact on the PV production, and however, the pc-Si technology represents the technology most influenced by the irradiation while the a-Si is the least influenced in the two installations.

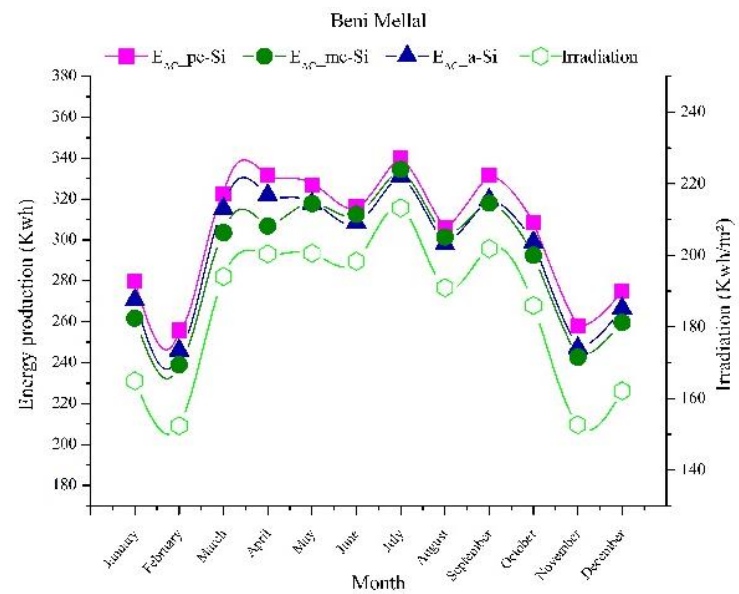

Figure 6. Monthly solar irradiation with monthly energy production in Beni Mellal

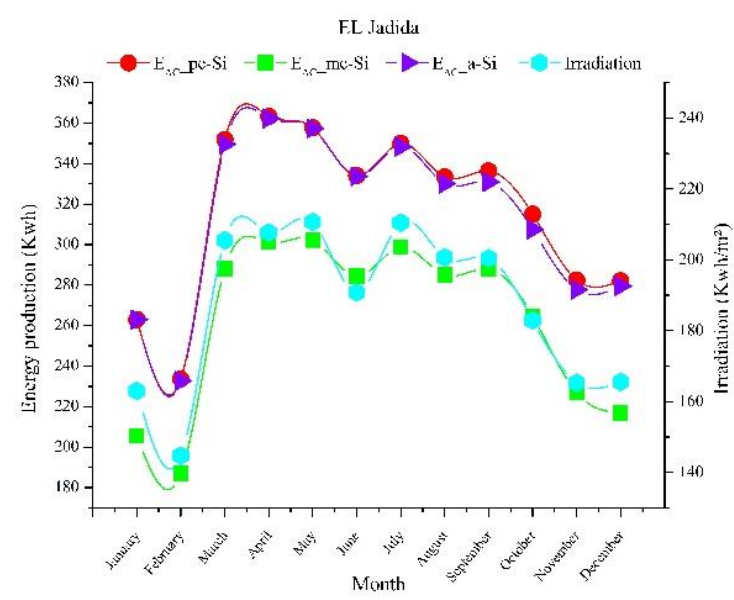

Figure 7. Monthly solar irradiation with monthly energy production in El Jadida

\subsubsection{Temperature}

Figures 8 and 9 show the influence of temperature on the photovoltaic production of mc-Si, pc-Si and a-Si technologies in Beni Mellal and El Jadida respectively, in both figures we observe an inverse behavior of temperature with respect to production photovoltaic, because the rise in temperature always coincides with the decrease in production and vice versa.

\subsubsection{Wind}

The Figures 10 and 11 represent the impact of wind speed on photovoltaic production in Beni Mellal and El Jadida [29] respectively. It is outstanding that most of the time the curve of the wind speed follows the same path as those of the production of the three technologies in the two cities, this explains the proportional correlation of the wind speed with the photovoltaic production for the three technologies under the two antagonistic climatic conditions. 


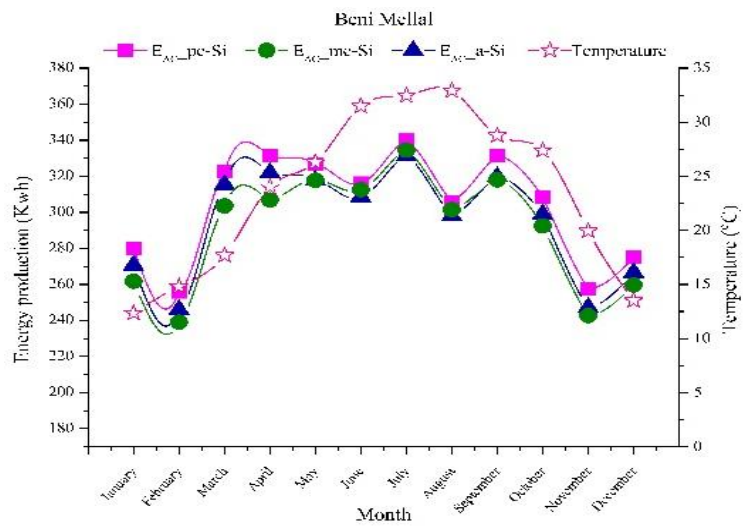

Figure 8. Monthly energy production with temperature in Beni Mellal

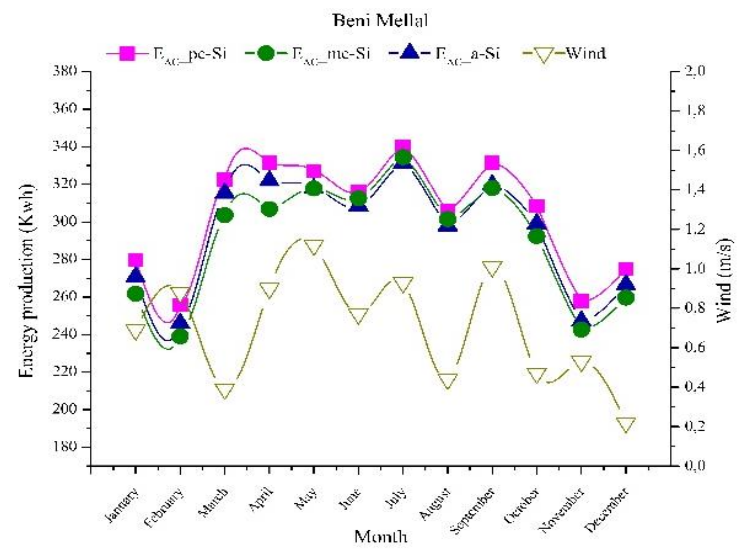

Figure 10. Monthly energy production with wind speed in Beni Mellal

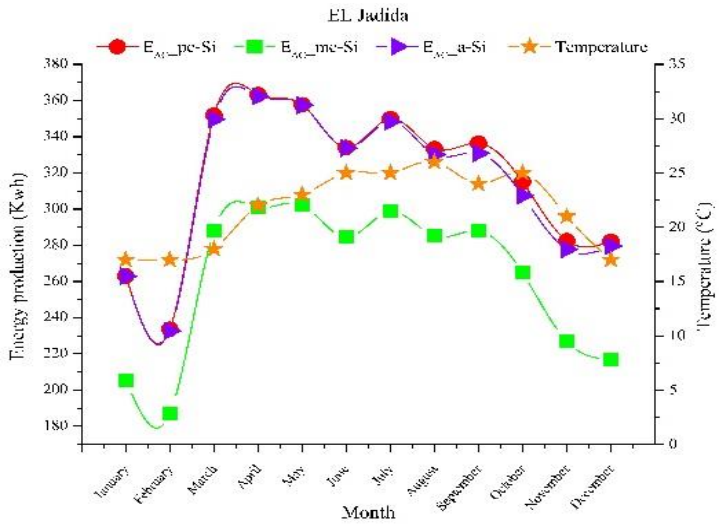

Figure 9. Monthly energy production with temperature in El Jadida

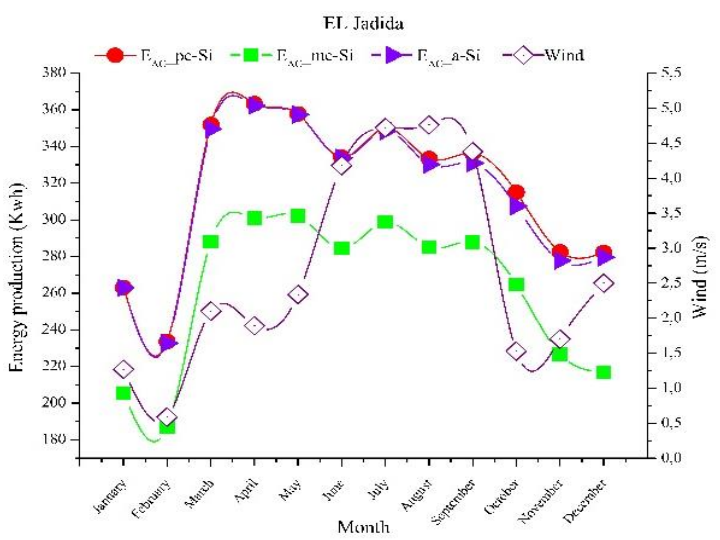

Figure 11. Monthly energy production with wind speed in El Jadida

\subsubsection{Humidity}

Figures 12 and 13 show the impact of humidity on photovoltaic production in Beni Mellal and El Jadida [29] respectively. The results depicted in the figures show that the humidity has an inversely proportional relation with the production of the solar panels for the three technologies in both locations since it generates cloud covers, as well as generates water grains under the glass of the panels which avoid sunlight to reach solar cells.

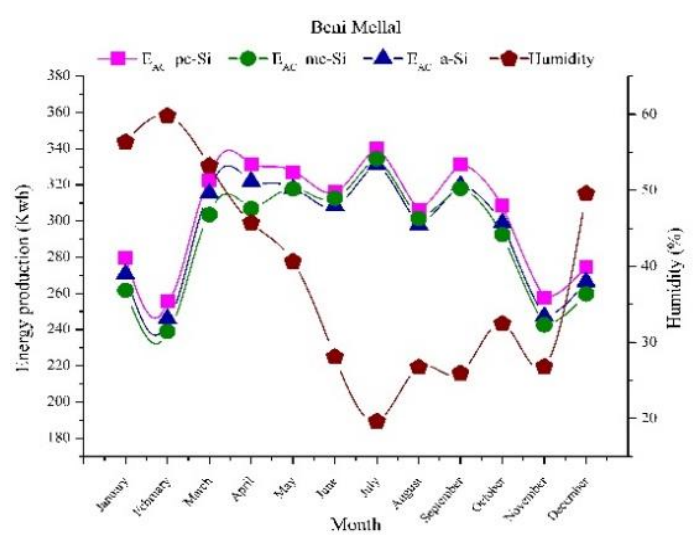

Figure 12. Monthly energy production with humidity in Beni Mellal

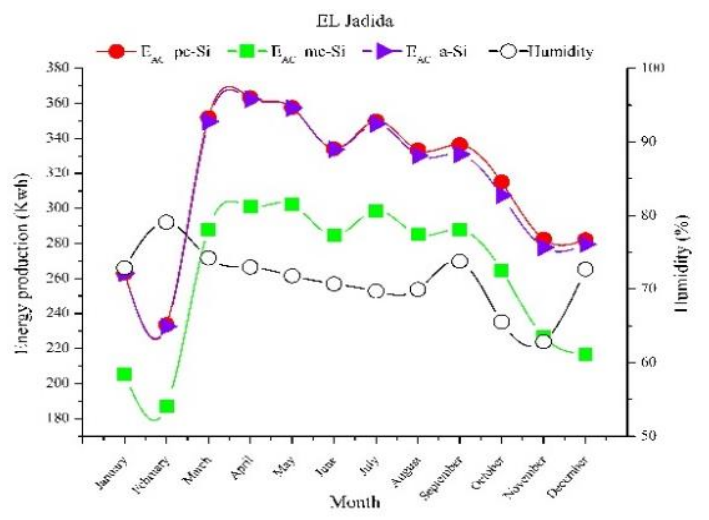

Figure 13. Monthly energy production with humidity in El Jadida 


\subsection{Performance analysis}

\subsubsection{PV plant production and final yield (Yf)}

In Figure 14 a comparison of the monthly photovoltaic energy produced in both cities (Beni Mellal and El Jadida) between the three technologies has been illustrated. The pc-Si in the two cities seems to be the most efficient type of technology compared to other technologies (mc-Si and a-Si). The annual energies injected into the gride by the pc-Si, mc-Si and a-Si photovoltaic plants in Beni Mellal were recorded respectively by $3652 \mathrm{kWh}, 3542 \mathrm{kWh}$ and $3491 \mathrm{kWh}$, while in El Jadida, were recorded in the same order by $3803 \mathrm{kWh}, 3773 \mathrm{kWh}$ and $3149 \mathrm{kWh}$. We deduce from these results that the pc-Si and mc-Si plants in El Jadida produce better than those in Beni Mellal, despite the fact that Beni Mellal is more irradiated than El Jadida. This contradiction can be explained by the high-temperature impact on the performance of crystalline silicon PV modules. In contrast, a-Si technology produces more in Beni Mellal than in El Jadida, taking advantage of the strong irradiation and the fact that it is less sensitive to high-temperatures than crystalline technology.

The monthly average variation final yield is depicted in Figure 15 . The monthly average final yield in Beni Mellal varies between a minimum of $4.30 \mathrm{~h} /$ day, $4.12 \mathrm{~h} /$ day and $4.04 \mathrm{~h} /$ day (in November) to a maximum of $5.53 \mathrm{~h} /$ day (in April and September), $5.37 \mathrm{~h} /$ day (in April) and $5.40 \mathrm{~h} /$ day (in July) for polycrystalline, monocrystalline and amorphous technologies, respectively. While in El Jadida the monthly average, final Yield varies between a minimum of $4.03 \mathrm{~h} /$ day, $4.01 \mathrm{~h} /$ day and $3.22 \mathrm{~h} /$ day (in February) to a maximum of $6.05 \mathrm{~h} / \mathrm{day}$, $6.04 \mathrm{~h} /$ day and $5.02 \mathrm{~h} /$ day (in April) for polycrystalline, monocrystalline and amorphous technologies, in the same order. From these results, it can be noted that the final yield values recorded are often high at El Jadida compared to Beni Mellal except in January and February due to its low incident solar radiation (Figure 6 and Figure 7) and the effect of temperature (Figure 8) which is raised in Beni Mellal.

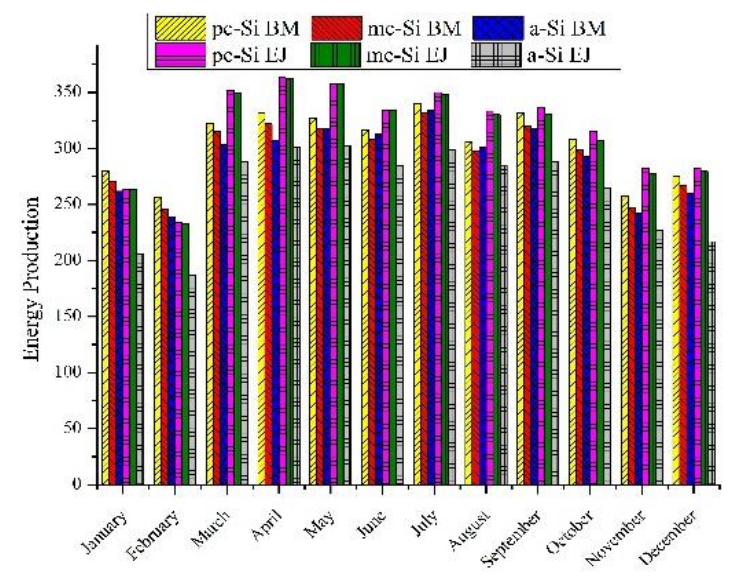

Figure 14. Energy production in El Jadida and Beni Mellal

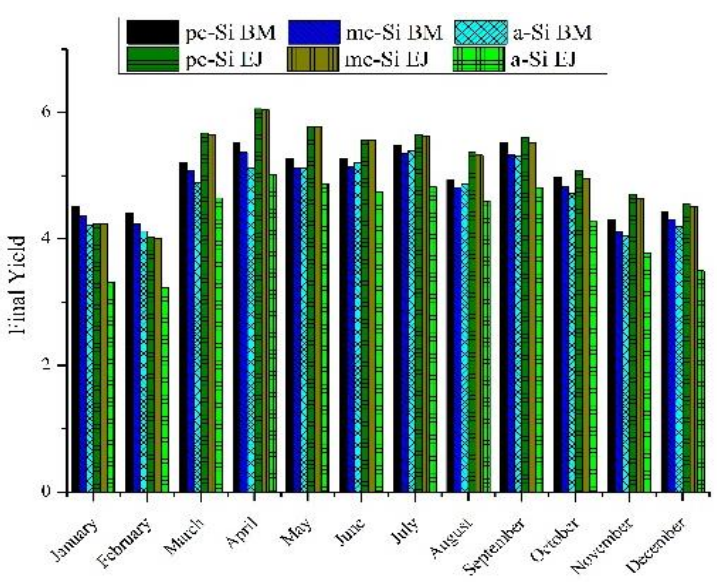

Figure 15. Monthly energy production with humidity in El Jadida

\subsubsection{Monthly energy density (MED)}

Figures 16 and 17 show the MED of the mini-plants studied (Beni Mellal and El Jadida respectively). The MED of the a-Si installation in Beni Mellal varies from 12.69 to $17.76 \mathrm{kWh} / \mathrm{m}^{2}$, whilst in El Jadida the MED of this technology varies from 9.93 to $16.04 \mathrm{kWh} / \mathrm{m}^{2}$ during the considered year. For pc$\mathrm{Si}$ and mc-Si installations, the MED varies from $19.04 \mathrm{kWh} / \mathrm{m}^{2}, 18.30 \mathrm{kWh} / \mathrm{m}^{2}$ in Beni Mellal to 25.29 $\mathrm{kWh} / \mathrm{m}^{2}, 24.65 \mathrm{kWh} / \mathrm{m}^{2}$ respectively; and from $17.39 \mathrm{kWh} / \mathrm{m}^{2}, 17.32 \mathrm{kWh} / \mathrm{m}^{2}$ in El Jadida to $27.03 \mathrm{kWh} / \mathrm{m}^{2}$, $26.96 \mathrm{kWh} / \mathrm{m}^{2}$ in the same order. A high value of energy density (ED) indicates better land use. From the results, it should be noted that for the two cities, pc-Si installations have the best ED, followed by mc-Si while a-Si represents the lowest ED value among the three technologies, this low value for the a-Si technology can be explained by the low level of general efficiency of the a-Si modules.

\subsubsection{Performance ratio $(P R)$}

Figures 18 and 19 illustrate the monthly performance ratio (PR) assessment. The annual average values of the performance ratio for $\mathrm{pc}-\mathrm{Si}, \mathrm{mc}-\mathrm{Si}$, and a-Si respectively are $83 \%$, $80 \%$, and $79 \%$ in $\mathrm{Beni}$ Mellal, and $85 \%, 84 \%$, and $70 \%$ in EL Jadida in the same order. The highest RP values for pc-Si in Beni Mellal were recorded in January by $85 \%$, while for $\mathrm{mc}-\mathrm{Si}$ and $\mathrm{a}-\mathrm{Si}$, the high values were observed in December by $82 \%$ and $80 \%$ respectively, however the highest values in El Jadida were observed for a-Si in 
May by $76 \%$, and for pc-Si and mc-Si in April by $90 \%$ for both. The results of the pc-Si and mc-Si technologies in Beni Mellal can be explained by the drop in temperature, which contributes to the minimization of capture losses, whereas the temperate climate and the high radiation intensity of El Jadida help it to produce better and therefore to have a better performance ratio. Nevertheless, during the warmer months, the amorphous silicon (a-Si) PV plant appears to be the least influenced by the high temperature.

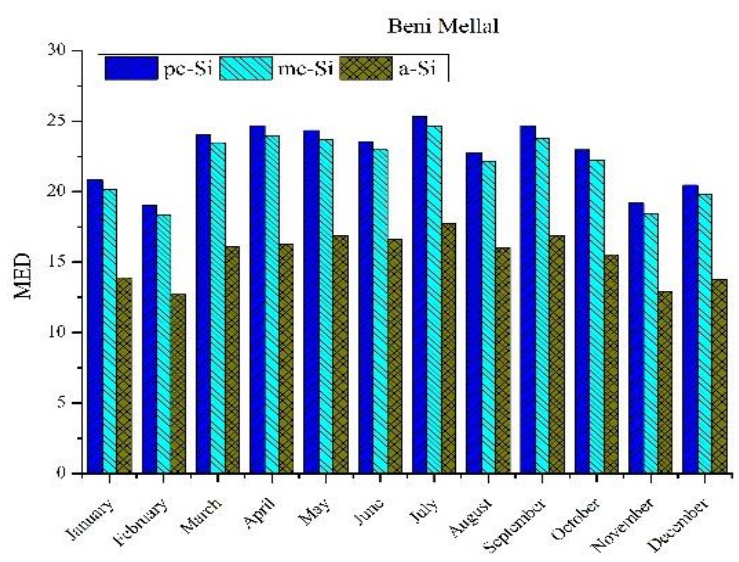

Figure 16. Monthly energy density by module technology in Beni Mellal

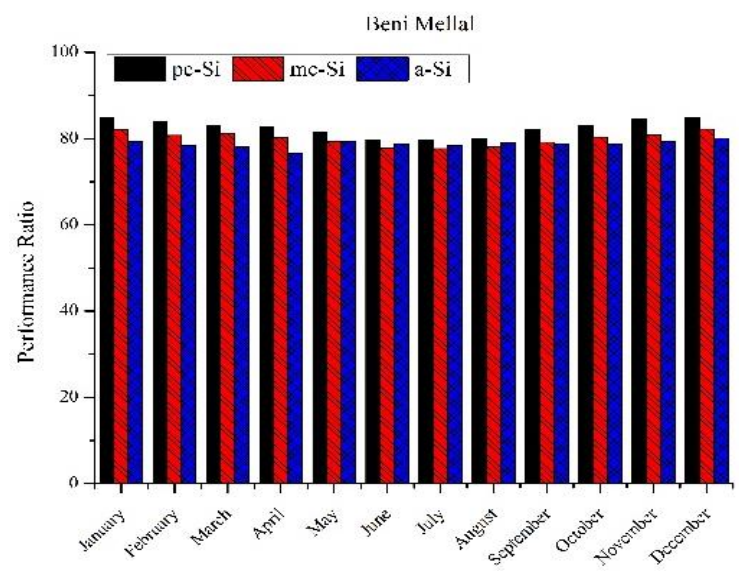

Figure 18. Monthly average values of performance Ratio in Beni Mellal

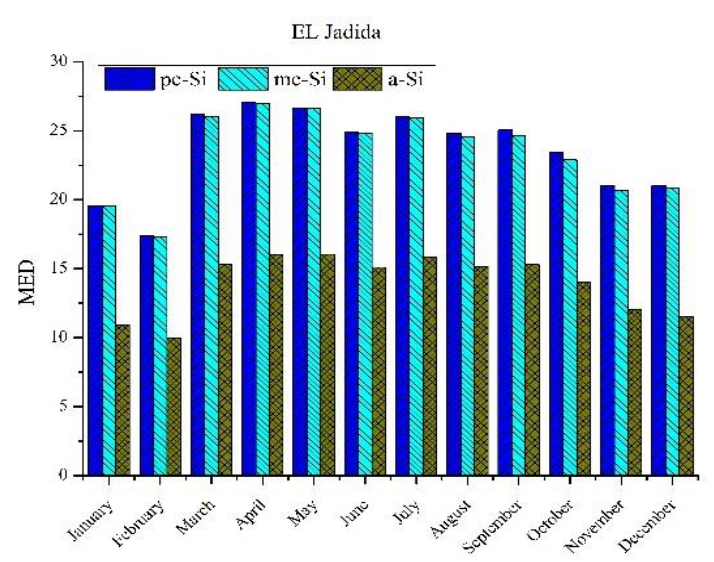

Figure 17 . Monthly energy density by module technology in El Jadida

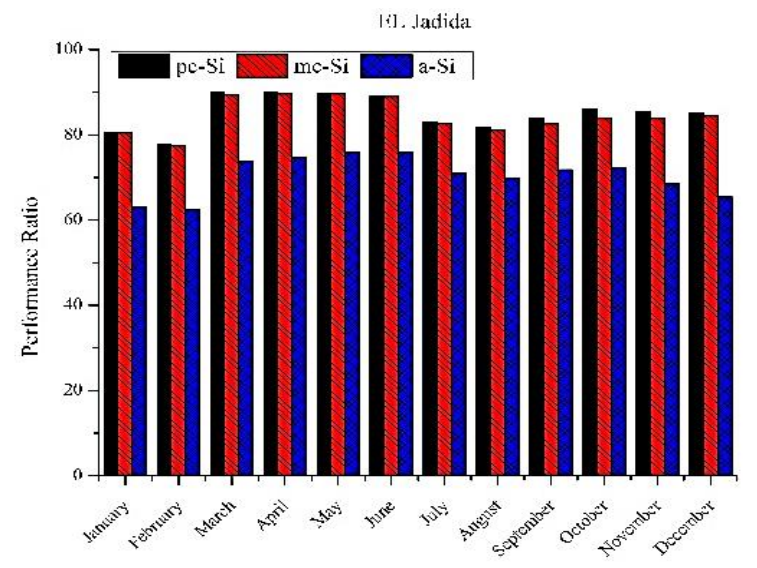

Figure 19. Monthly average values of performance Ratio in El Jadida

\subsubsection{Capacity factor $(\mathrm{CF})$}

Figure 20 represents the capacity factor for tow PV plants, according to the results shown in this figure, the highest value of capacity factor in both cities have been recorded by pc-Si, with $7.08 \%$ and $7.57 \%$ followed by mc-Si with $6.90 \%$ and $7.55 \%$ then a-Si with $6.97 \%$ and $6.30 \%$ for Beni Mellal and El Jadida respectively. Furthermore, for both pc-Si and mc-Si, El Jadida has been registered the highest values of CF except in January and February wherein Beni Mellal which recorded the highest values, while for a-Si Beni Mellal presents the highest values during all year.

\subsubsection{PV efficiency}

Figures 21 and 22 represent the efficiency of the photovoltaic modules at Beni Mellal and El Jadida respectively. Based on these findings, pc-Si technology denotes the most effective one of the three technologies in both cities, the efficiency values of pc-Si modules, range from a minimum of $11.86 \%$ recorded in July to a maximum of $12.62 \%$ reached in December in Beni Mellal, though in El Jadida, this one varies between $12.01 \%$ registered in February and $13.03 \%$ recorded in June. For mc-Si technology, the values range from $11.56 \%$ to $12.23 \%$ in Beni Mellal, and from $11.96 \%$ to $13.02 \%$ in El Jadida. While a-Si 
technology registered a percentages of PV efficiency vary between $11.39 \%$ and $11.92 \%$, and between $9.38 \%$ and $11.09 \%$ in Beni Mellal and El Jadida respectively.

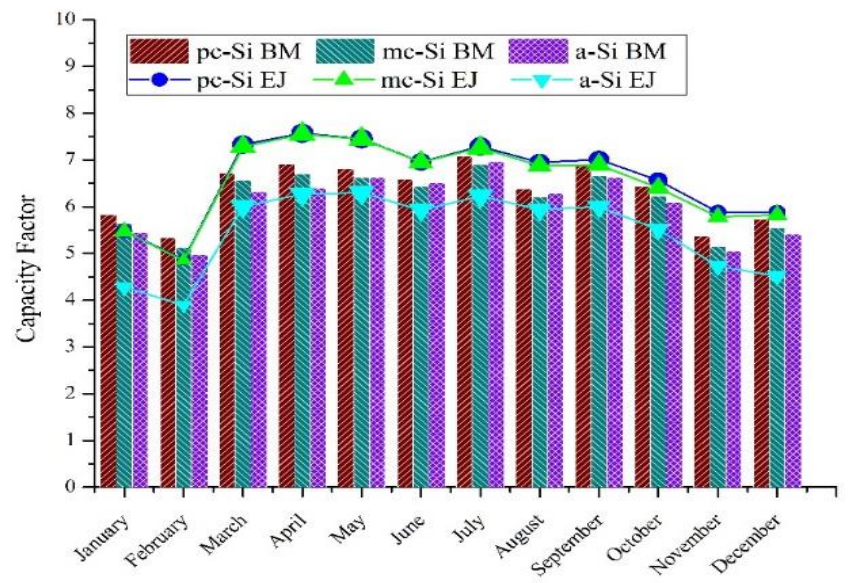

Figure 20. Evolution of monthly capacity factors in El Jadida and Beni Mellal PV plants

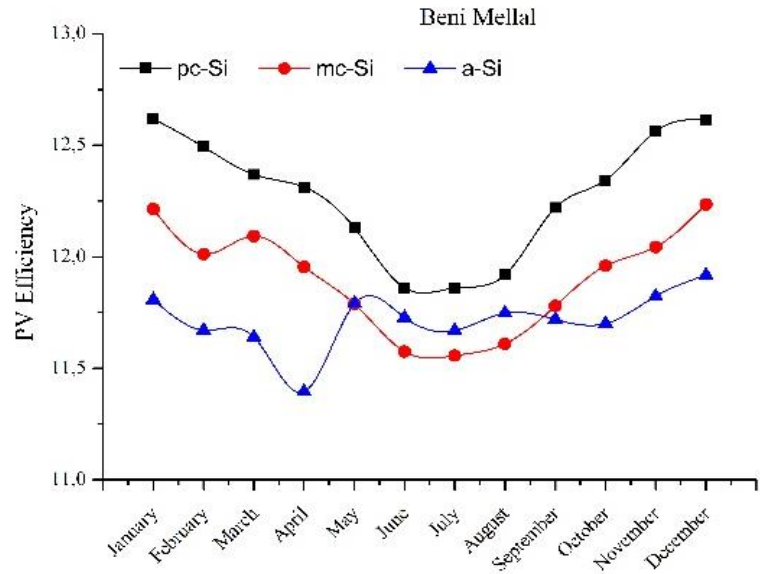

Figure 21. PV efficiency by module technology in beni Mellal

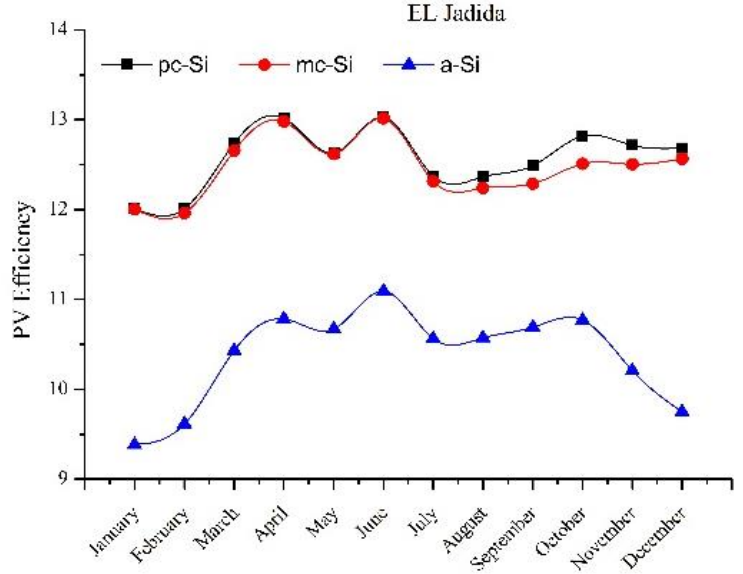

Figure 22. pv efficiency by module technology in El Jadida

\section{CONCLUSION}

In this work, a comparative evaluation of two mini-grid-connected PV plants based on three silicon technologies (polycrystalline, monocrystalline and amorphous), under Beni Mellal and El Jadida (Morocco) climatic conditions is carried out. Whether in terms of RP or PV efficiency, the most performant technology for power generation is $\mathrm{pc}-\mathrm{Si}$, as it always presents the best results in both cities' installations despite their antagonistic character in terms of climate. Overall, we see that regardless of the indicator used to compare the performance of two PV plants, El Jadida always produces better than Beni Mellal, even though Beni Mellal's solar irradiation is better than El Jadida, that is to say solar irradiation alone is not sufficient to conclude the photovoltaic productivity in a given location, the ambient temperature and irradiation are both extremely important to determine the solar cells behavior. nevertheless, even if the results represent direct correlations between production and wind speed and conversely between production and humidity in the two cities, these two parameters (humidity and wind speed) turn out to have less impact on photovoltaic production. However, the obtained results show that the ambient temperature has a greater impact on the mc-Si than on the pc-Si. Nevertheless, a-Si is the least technology that influenced by temperature. These results can absolutely offer beneficial information to managers and investors for an appropriate choice of module technology with considering site conditions. 


\section{REFERENCES}

[1] C. Bahanni, M. Adar, S. Boulmrharj, M. Khaidar, and M. Mabrouki, "Analysis of weather impact on the yield of PV plants installed in two antagonists cities in Morocco," 2020 5th International Conference on Renewable Energies for Developing Countries (REDEC), 2020, pp. 1-6, doi: 10.1109/REDEC49234.2020.9163841.

[2] P. Mints, Solar PV Supply and Demand 2018: Is this a crossroads for the PV Industry?, 2018. Accessed: Nov. 20, 2018. [Online]. Available:https://www.intersolarglobal.com/fileadmin/Intersolar-

Global/Webinars/North_America/20181120_Intersolar_North_America_Webinar_Solar_PV_Supply_and_Demand_2018_by_Paula_Min ts.pdf

[3] E. Despotou, "Vision for photovoltaics in the future," Comprehensive Renewable Energy, vol. 1, pp. 179-198, 2012, doi: 10.1016/B978-0-08-087872-0.00109-8

[4] M. A. Green, K. Emery, Y. Hishikawa, W. Warta, and E. D. Dunlop, "Solar cell efficiency tables (version 40)," Progress in photovoltaics, vol. 20, no. 5, pp. 606-614, 2012, doi: 10.1002/pip.2267.

[5] T. Huld, R. Gottschalg, H. G. Beyer, and M. Topič, "Mapping the performance of PV modules, effects of module type and data averaging," Solar Energy, vol. 84, no. 2, pp. 324-338, 2010, doi: 10.1016/j.solener.2009.12.002.

[6] B. M. Dawoud and S. C. Lim, "Performance comparison of fixed and single axis tracker photovoltaic system in large scale solar power plants in Malaysia," Indonesian Journal of Electrical Engineering and Computer Science, vol. 21, no. 1, pp. 10-17, 2021, doi: 10.11591/ijeecs.v21.i1.pp10-17.

[7] M. N. Raj and J. Pasupuleti, "Performance assessment of a $619 \mathrm{~kW}$ photovoltaic power plant in the northeast of peninsular Malaysia," Indonesian Journal of Electrical Engineering and Computer Science, vol. 20, no. 1, pp. 9-15, 2020, doi: 10.11591/ijeecs.v20.i1.pp9-15.

[8] A. M. Ates and H. Singh, "Rooftop solar Photovoltaic (PV) plant - performance analysis and critical evaluation," Journal of King Saud University - Science, vol. 33, no. 3, 2021, doi: 10.1016/j.jksus.2021.101361.

[9] I. Omar Nour-eddine, B. Lahcen, O. H. Fahd, B. Amin, and O. Aziz, "Outdoor performance analysis of different PV technologies under hot semi-arid climate,” Energy Reports, vol. 6, no. 6, pp. 36-48, 2020, doi: 10.1016/j.egyr.2020.08.023.

[10] E. Roumpakias and A. Stamatelos, "Comparative performance analysis of grid-connected photovoltaic system by use of existing performance models," Energy Conversion and Management, vol. 150, pp. 14-25, 2017, doi: 10.1016/j.enconman.2017.08.001.

[11] M. E. H. Jed, R. Ihaddadene, N. Ihaddadene, C. E. E. Sidi, and M. E. Bah, "Performance analysis of 954,809 kWp PV array of Sheikh Zayed solar power plant (Nouakchott, Mauritania)," Renewable Energy Focus, vol. 32, pp. 45-54, 2020, doi: 10.1016/j.ref.2019.11.002.

[12] M. Al-Addous, Z. Dalala, C. B. Class, F. Alawneh, and H. Al-Taani, "Performance analysis of off-grid PV systems in the Jordan Valley," Renewable Energy, vol. 113, pp. 930-941, 2017, doi: 10.1016/j.renene.2017.06.034.

[13] E. Elibol, Ö. T. Özmen, N. Tutkun, and O. Köysal, "Outdoor performance analysis of different PV panel types," Renewable and Sustainable Energy Reviews, vol. 67, pp. 651-661, 2017, doi: 10.1016/j.rser.2016.09.051.

[14] D. H. Daher, L. Gaillard, M. Amara, and C. Ménézo, "Impact of tropical desert maritime climate on the performance of a PV grid-connected power plant," Renewable Energy, vol. 125, pp. 729-737, 2018, doi: 10.1016/j.renene.2018.03.013.

[15] A. Haffaf, F. Lakdja, D. O. Abdeslam, and R. Meziane, "Monitoring, measured and simulated performance analysis of a $2.4 \mathrm{kWp}$ grid-connected PV system installed on the Mulhouse campus, France,” Energy for Sustainable Development, vol. 62, pp. 44-55, 2021, doi: 10.1016/J.ESD.2021.03.006.

[16] M. E. H. Dahmoun, B. Bekkouche, K. Sudhakar, M. Guezgouz, A. Chenafi, and A. Chaouch, "Performance evaluation and analysis of grid-tied large scale PV plant in Algeria," Energy for Sustainable Development, vol. 61, pp. 181-195, Apr. 2021, doi: 10.1016/j.esd.2021.02.004

[17] A. Gopi, K. Sudhakar, W. K. Ngui, I. M. Kirpichnikova, and E. Cuce, "Energy analysis of utility-scale PV plant in the raindominated tropical monsoon climates," Case Studies in Thermal Engineering, vol. 26, Aug. 2021, doi: 10.1016/j.csite.2021.101123.

[18] P. Bevilacqua, R. Bruno, and N. Arcuri, "Comparing the performances of different cooling strategies to increase photovoltaic electric performance in different meteorological conditions," Energy, vol. 195, Mar. 2020, doi: 10.1016/j.energy.2020.116950.

[19] A. Ziane et al., "Photovoltaic output power performance assessment and forecasting: Impact of meteorological variables," Solar Energy, vol. 220, pp. 745-757, May 2021, doi: 10.1016/j.solener.2021.04.004.

[20] A. Murat Ates and H. Singh, "Rooftop solar Photovoltaic (PV) plant - One year measured performance and imulations," Journal of King Saud University - Science, vol. 33, no. 3, May 2021, doi: 10.1016/j.jksus.2021.101361.

[21] International Energy Agency, Energy Policies Beyond IEA Countries, 2019. Accessed: Apr. 14, 2021. [Online]. Available: https://iea.blob.core.windows.net/assets/138e3195-d0e6-4345-a66c-92ebe4abbeaf/Energy_Policies_beyond_IEA_Countries_Morocco.pdf

[22] M. Adar, Y. Najih, M. Gouskir, A. Chebak, M. Mabrouki, and A. Bennouna, "Three PV plants performance analysis using the principal component analysis method," Energy, vol. 207, 2020, doi: 10.1016/j.energy.2020.118315.

[23] M. Adar, H. Bazine, Y. Najih, C. Bahanni, M. Mabrouki, and A. Chebak, "Simulation Study of three PV Systems," 2018 6th International Renewable and Sustainable Energy Conference (IRSEC), 2018, pp. 1-5, doi: 10.1109/IRSEC.2018.8702827.

[24] M. Adar, Z. Khaouch, M. Mabrouki, A. Benouna, and A. Chebak, "Performance Analysis of PV Grid-Connected in Fours Special Months of the Year," 2017 International Renewable and Sustainable Energy Conference (IRSEC), 2017, pp. 1-5, doi: 10.1109/IRSEC.2017.8477373.

[25] N. Erraissi, M. Raoufi, N. Aarich, M. Akhsassi, and A. Bennouna, "Implementation of a low-cost data acquisition system for 'PROPRE.MA' project," Measurement, vol. 117, pp. 21-40, 2018, doi: 10.1016/j.measurement.2017.11.058.

[26] M. Kottek, J. Grieser, C. Beck, B. Rudolf, and F. Rubel, "World map of the Köppen-Geiger climate classification updated," Meteorologische Zeitschrift, vol. 15, no. 3, pp. 259-263, 2006, doi: 10.1127/0941-2948/2006/0130.

[27] Google Maps. Accessed Apr. 03, 2021. [Online]. Available: www.google.com/maps/@32.3772878,$6.3187493,191 \mathrm{~m} / \mathrm{data}=! 3 \mathrm{~m} 1 ! 1 \mathrm{e} 3$

[28] Google Maps. Accessed Apr. 03, 2021. [Online]. Available: www.google.com/maps/@33.225388,$8.4861296,186 \mathrm{~m} / \mathrm{data}=! 3 \mathrm{~m} 1 ! 1 \mathrm{e} 3$

[29] Global Modeling and Assimilation Office (GMAO), MERRA-2 tavg1_2d_slv_Nx: 2d,1-Hourly,Time-Averaged,SingleLevel,Assimilation,Single-Level Diagnostics V5.12.4, Greenbelt, MD, USA, Goddard Earth Sciences Data and Information Services Center (GES DISC), 2015, doi: 10.5067/VJAFPLI1CSIV. Accessed: Mar. 04, 2021. [Online]. Available: https://disc.gsfc.nasa.gov/datasets/M2T1NXSLV_5.12.4/summary 


\section{BIOGRAPHIES OF AUTHORS}
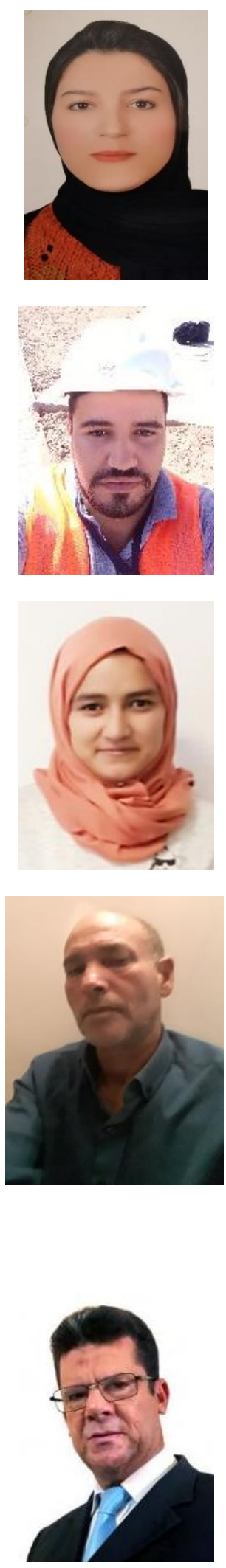

Caouthar Bahanni (iD $\mathrm{SC}$ S $\mathrm{P}$ received the license degree in mechanical engineering from Hassan 1 university, Settat, Morocco, in 2015 and the master degree in mechanical production technology from Abdelmalek Essaadi University, Tetouan, Morocco, in 2017. She is currently $\mathrm{PhD}$ student in the Industriel Engineering Laboratory at University of Science and Technology, Beni Mellal, Morocco. Her current research interests include artificial intelligence in the field of photovoltaic solar energy and applications in PV plant installed in the roof of the faculty by the team of PROPRE.MA project. She can be contacted at email: Caouthar.bahanni@usms.ma.

Mustapha Adar (iD 8D SC P is a Doctor in Materials and Energy from the Faculty of Science and Technology of Sultan Moulay Slimane University, Morocco. He is a researcher in renewable energy and material surface and interface engineering. Previously, he was a contract professor of physics at the Polydisciplinary Faculty of Sultan Moulay Slimane University. President of the USMS- Young Minds Section of the European Physical Society. He can be contacted at email: adar.mustapha@gmail.com.

Sofia Boulmrharj (iD) $\mathrm{SC}$ S is a post-doctoral researcher at the International University of Rabat (UIR). She holds a PhD degree in Physics-Energetic from the Faculty of Sciences at Chouaib Doukkali University in El Jadida in September 2020. Her PhD work was prepared at UIR within the framework of MIGRID (USAID-PEER program, 2017-2020) and PROPRE (IRESEN, 2013-2018) projects. She has published a number of papers in international peerreviewed journals, books, and conferences. Her main research focus is on the integration of renewable energy sources and storage systems into smart micro-grids for buildings together with their sizing and modeling. She has actively been working in the area of energy storage. She can be contacted at email: sofia.boulmrharj@uir.ac.ma.

Mohammed Khaidar (D) $8 \mathrm{SC}$ P received $\mathrm{PhD}$ degree (Doctorat d'Etat ès-Sciences Physiques) from the Cadi Ayyad University of Marrakech (UCA), Morocco, in 1989, and a 3rd cycle Doctorate form National Polytechnic Institute, INP-G, Grenoble/France, 1981. Expert in EcoEnv (Environment Economy). Since 1981, he was Research - Teacher in Cadi Ayyad University -Marrakech and Chouaib Doukkali University - El Jadida/Morocco. He was supervisor of several PhD. He was initiator and manager of CUR' EnR\&SIE' (University Research Center in Renewable Energies and Smart Systems for Energy -UCD), since its creation in 2017 until 2019. He was coordinator GRIPAS - UCD (Interdisciplinary Research group on Soil Preservation and Improvement) (1999-2002) and regional coordinator of PROPRE (University research consortium for mapping photovoltaic productivity in Morocco) (2013-2018). His research interests focused on the fields of material sciences, thin films and renewable energies. Recently, he is conducting research in the fields of renewable energy Integration into Smart Building, environmental sciences and precision agriculture. He can be contacted at email: khaidar.medd@gmail.com.

Mustapha Mabrouki (D) SI SC P currently works at the Physics Department, University Sultan Molay Slimane Faculty of Science and Technology, Beni Mellal, Morocco. He does research in Smart grids and smart cities, Photovoltaic Materials Synthesis and Integration, Phosphates and derivatives, Biotechnology and Microbiology. His current projects are i) 'PROPRE.MA'. Build photovoltaic yield maps of grid connected mono, poly and amorphous PV modules for all Morocco with land calibration on 20 identical plants. ii) AFM project, iii) Phosphate project, iv) Solar Decathlon Africa competition. He can be contacted at email: mus_mabrouki@yahoo.com. 